\title{
Nicholas Roosevelt in A Front Row Seat
}

\author{
Hungary in the 1930s As Reflected in the Memoirs of an \\ American Diplomat
}

\begin{abstract}
As Nicholas Roosevelt put it in the foreword of his memoirs a "combination of circumstances gave [him] the front row seat at numerous important [...] events in Europe during the interwar period," which made it possible for him to "study history in the making" both as a journalist working for acknowledged dailies of the time, such as The New York Times and The New York Herald Tribune, and as a diplomat who served at various European posts in Europe including Hungary between 1930 and 1933. Due to both of these positions Hungarians considered Roosevelt a highly influential person, who could possibly air and expose Hungary's situation in the international community after World War I, and help further the revision of the Treaty of Trianon. Drawing on his memoirs, diplomatic exchanges, as well as a selection of his newspaper and magazine articles, the essay proposes to reflect on how Roosevelt viewed Hungary, and whether his various forms of written narratives could have any effect and exert any influence in this regard.

Keywords: Nicholas Roosevelt, American diplomat, American-Hungarian relations, interwar period
\end{abstract}

Nicholas Roosevelt served as U.S. minister to Hungary between 1931 and 1933. He was a career diplomat who spent a considerable amount of time in Central Europe in various capacities and on different diplomatic missions, therefore, he had obtained a deep understanding of and knowledge about the region. Due to his experience he deservedly earned the recognition as the expert on Central European affairs. 


\section{The diplomat writer and writer diplomat: Nicholas Roosevelt's career}

Nicholas Roosevelt, journalist, diplomat, and author received prominent education majoring in History at Harvard, one of the most competitive and prestigious American universities. Well before he earned his degree and finished his studies, young Roosevelt got the opportunity to get involved in international relations, and pursued a remarkable career both in diplomacy and journalism.

In 1914 Roosevelt assumed the position of an embassy attaché and began to work as the secretary to Special Assistant of U.S. Ambassador to Paris John Work Garrett. Prior to American entry into World War I, between 1916 and 1917, he served in Europe as secretary of a special mission of the American International Corps. During the Great War Roosevelt distinguished himself as an infantry captain, and later as assistant chief of staff of the $81^{\text {st }}$ Division (also known as the Wildcats). Following the armistice on November 13, 1918 - partly in recognition of his merits - he had been honored to join the American Delegation to Negotiate Peace and, as one of the ten presidential aides, he accompanied President Thomas Woodrow Wilson to the Paris Peace Conference. ${ }^{1}$ This short and, as Roosevelt evaluated it in his memoirs, rather eventless interlude ${ }^{2}$ ushered one of the most significant turning points throughout his professional life. Professor of History Archibald Carry Coolidge of Harvard fame, one of the experts of the Inquiry invited his former student to join his field mission to Vienna for the American Delegation to Negotiate Peace, which was "assigned [...] for the purpose of proceeding to Austria [...] to observe political conditions in Austria-Hungary and neighboring countries;"3 furthermore advise the American delegation and prepare policy proposals for them pertaining to the countries of the region. ${ }^{4}$

In 1919 Roosevelt "hailed the opportunity,"5 and thereby he joined the Allied Military Mission to Vienna and Budapest. "The collapse of the Austro-Hungarian Empire meant a complete reorientation in central and eastern Europe. Vienna," as Roosevelt believed, "would be the best place to see history in the making. To a would-be historian this was a chance of a life-time. To be there under Coolidge would be particularly interesting as he had a scholarly knowledge of Europe and was wise and shrewd in appraising conflicting claims, statements, and influences." 6 Therefore, the 
work with Coolidge could considerably enhance Roosevelt's understanding of the real nature of the Central European problems.

Roosevelt had proven right: soon after he commenced his mission in Vienna, in March 1919 he was instructed to go to Budapest in the company of Professor of International Law Philip Marshall Brown, another renowned member of the Coolidge Mission. Upon their arrival in Budapest on March 17, 1919 Hungarian communist leader Béla Kun assumed power, thus Roosevelt could eyewitness the red revolution and take-over in the Hungarian capital from the front row seat. ${ }^{7}$ Roosevelt's stay in Europe temporarily ceased in May 1919 when Secretary of State Robert Lansing unexpectedly recalled the members of the Coolidge Mission from Europe, thus Roosevelt returned home. Of this he remembers in the following way: "Glad as I was to get home and to turn my back on the problems of [E]astern Europe which we had watched so futilely, my interest in the area persisted, and in the succeeding years I welcomed the occasional contacts with friends from Austria and Hungary."8

Following the war, Roosevelt started his career as a journalist: in 1921 he joined the staff of The New York Tribune. His comprehensive knowledge of and his extended experience in European political and economic affairs made him an excellent choice as a foreign correspondent for several other newspapers, including, for example, the Neue Freie Presse, the Paris-based Le Temps, and De Haagsche Post in the Hague. 9 From 1923 Roosevelt assumed the position of senior editorial staff member and correspondent at The New York Times, which eventuated the opportunity for him again to go to Central Europe to report about the financial and economic issues of the region.

Following a rather short, yet stormy interlude in the Philippines (he was nominated for Vice Governor but never assumed the position), the U.S. State Department assigned him a new mission in Central Europe primarily due to Roosevelt's unquestionable and highly recognized expertise on and vetted interest in Central European affairs. In 1930 President Herbert Hoover appointed him U.S. minister extraordinary and plenipotentiary to Budapest, Hungary. "[I]n addition to obtaining information about Hungary, the department wanted me to study the economic conditions in the neighbor nations and co-ordinate this information in compact, nontechnical form. [...] This broader scope of my mission gave it an added interest [...], says Roosevelt in his memoirs; ${ }^{10}$ especially with view to the fact that he arrived in Central 
Europe shortly after the economic crisis set in, severely affecting the economy of Hungary and that of the successor states. In 1933 Roosevelt resigned his post, and, thus, he concluded his career in foreign service. He continued to work in public life and devoted his life to journalism writing for the New York Herald Tribune, and then again The New York Times, ${ }^{11}$ and he became an acclaimed author of numerous monographs. The list of Roosevelt's books is rather extensive: besides the ones discussing political issues including The Philippines: A Treasure and a Problem (1926), The Restless Pacific (1928), American and England? (1930), The Townshend Plan (1936), A New Birth of Freedom (1938), and Theodore Roosevelt: The Man As I Knew Him (1967), Roosevelt, as an ardent advocate of conservationism, penned Conservation: Now or Never (1970), as he occasionally also published in more popular genres, for example, Creative Cooking and Good Cooking. The present essay proposes to analyze his memoirs, A Front Row Seat, published by the University of Oklahoma Press in 1953.

As is explained above, throughout his career Roosevelt as a diplomat and as a writer truly had the chance to eyewitness history "from a front row seat," 12 and to chronicle ${ }^{13}$ great twentieth-century events and turning points of European history (such as, for example, the dismemberment of Austria-Hungary, the negotiations of the Paris Peace Conference, revolutions, and the consequences of the Great Depression). "A combination of circumstances gave me a front row seat at numerous important international and national events during the last forty years. About most of these I wrote at a time, often in diaries and letters, occasionally in books, usually in newspapers and magazines, and for several years in diplomatic dispatches to the Department of State." 14 Roosevelt had proven to be an excellent writer and journalist; his recollections duly demonstrate his expertise and talent in both fields.

Roosevelt's memoirs - though it offers its readers the sum total of his recollections and experiences filtered through his personal views and opinions - are by no means fiction, "flawed, imperfect," or "unverifiable history." 15 A Front Row Seat, composed in good taste and with a refined flair of words, reads as an authentic historical source, the work of a journalist and diplomat who watched and reported about the events of history with the shrewd eyes of a "recording observer."16 As Roosevelt explained: "The interrelationship between journalism [writing] and history is closer than many newspapermen - and nearly all historians admit. Much of today's news will be history tomorrow." Therefore, 
following the non-negotiable ideals of credibility and authenticity, he strongly believed that as a journalist and writer he could do a lasting service to historiography. ${ }^{17}$

\section{Hungary at the beginning of the 1930s, as Roosevelt saw it from a "front row seat"}

When in 1931 Roosevelt assumed his position as U.S. minister to Budapest, he arrived in a region which he knew well. This familiarity, however, had not generated any attachment to this place throughout the years at the legation in the Hungarian capital. His cold, reserved attitude and his critical opinion are reflected in the respective chapters of his memoirs as well as his diplomatic correspondence with the State Department, and are demonstrated in a somewhat exaggerated way by the following lengthy quote:

[...] Budapest in the thirties was still a gay capital. It was not, of course and never had been - a cosmopolitan center like Vienna, rich in tradition and in monuments of past greatness. Rather it was a provincial town, with few old historical landmarks. The more I saw of Budapest, the more I realized that the skyline of Buda, dominated by the Royal Palace, was symbolic of the nation - an imposing façade designed to give the illusion of magnificence and strength. The palace was an impressive tribute to the Hungary of the Magyar's dreams - a spacious and imposing residence for a great emperor or all-powerful king of a mighty nation. But it was - and had been since it was built - an empty shell in which no king had lived for more than a night. The modern statues of Hungary's historical heroes on the bastion adjoining the palace were arresting - from a distance. But they represented Hungarian heroes of old as modern protagonists would like them to look - big, strong, fierce warriors, riding great Roman steeds - whereas in actual life they were probably no larger than their rather small, stocky descendants, and rode the same kind of tough, scraggy ponies still to be found on the Hungarian plains - as different from the Roman and the imperial Austrian horses as mongrel hound from blooded bird dog.

Externally the Hungarians - especially those of the upper class were Westernized. But in many ways they retained Oriental traits - the love of face, the unquestioning acceptance of caste and position, the preference for pleasant pretenses over unpleasant truths. ${ }^{18}$ 
For Roosevelt contemporary Hungary was but a bygone world existing only in the imagination of the Hungarians who refused to face the political and historical changes and the geopolitical consequences of World War I, where semi-feudal social relations still prevailed. Roosevelt's judgement on Hungary was partly fed by his assumptions of the consequences of the Trianon Peace Treaty, and subsequently his views on Hungarian revisionist aspirations to rectify the frontiers of historic Hungary.

The revision of the Hungarian peace treaty comprised one of the most important issues on the political agenda in Hungary during the period between the world wars. Notwithstanding the fact that official Hungary had a rather limited scope of action in this regard, Hungarians directed their revisionist policies through various semi-official and popular channels, mainly towards Britain and France, and, interestingly, the United States of America. The revisionist expectations towards the U.S. were based on wishful thinking. Hungarians considered America as arbiter mundi and the symbol of justice and fair play, and based on some misconceptions and false beliefs, mostly pertaining to, among others, the idea of national self-determination as in proclaimed in Wilson's Fourteen Points and the resolutions of the 1921 American-Hungarian separate peace entertained unfounded expectations - with no regard to political and diplomatic realities. ${ }^{19}$ This explains why American ministers to Budapest during the interwar years enjoyed such an attention. Nicholas Roosevelt was no exception.

Roosevelt was regarded as "the best-informed American in Central Europe," 20 who, due to his profession, secured wide-spread contacts with American political and business circles as well as an extended social network, thus, social capital. Therefore, duly reflecting the contemporary hierarchical social relations, Hungarians considered Roosevelt as "the important American connection" and expected him to further the Hungarian cause, most importantly the revision of the Trianon borders. As is argued in the September 23, 1933 issue of 8 Órai Ujság [Eight o'clock news]: "Mr. Roosevelt is not only a diplomat but also a journalist who writes striking articles for the best American reviews and dailies. His sympathy therefore not only means that he communicates the favorable impressions gained in Hungary in an official quality but he gives even greater publicity to the same." 21 Several of Roosevelt's cordial statements suggest that he often paid diplomatic lip service when he offered "the publicity of the American papers in the interest of Hungary."22 At the same time he carefully avoided becoming a "well-meaning American" 
giving unsolicited advice and opinion that might be misunderstood by Hungarians. ${ }^{23}$ His memoirs and diplomatic correspondence reveal that Roosevelt had a cautious and critical view of the Hungarian attempts at the revision of the Treaty of Trianon. Roosevelt's attitude fell in line with the policy of the U.S. State Department which explicitly instructed the American ministers to Budapest to refrain from giving any statements and opinion on the Hungarian question. ${ }^{24}$

Roosevelt had understood the "fundamentals of the Danubian problem" 25 well. He was in Paris when the post war settlement was in the making. He experienced "the messianic quality" ${ }^{26}$ of President Wilson's arrival in Paris, the enthusiasm Wilson's speeches had aroused, and the hopes they incited among the peoples of Europe, including Hungary as well. At the same time Roosevelt had no illusions about the peace makers, "the Commissioners (principal members of the American delegation including Wilson, Colonel Edward M. House, General Tasker Bliss, Mr. Henry White, and Secretary of State Robert Lansing) [who] seemed ineffective," as Roosevelt explains mainly due to President "Wilson's lone-wolf technique"27: "whatever initiative these men had was stymied by Mr. Wilson's individualistic method of work." 28 As a consequence, "national interests were in constant and often irreconcilable conflict, points were yielded only reluctantly, and then only in exchange for concessions which could be profitably paraded by the beneficiary. The resulting treaties thus foredoomed to be unsatisfactory." 29

While Roosevelt was aware of the problems of the peace treaties, at the same time he saw the dismemberment of the Austro-Hungarian Monarchy as inevitable: as "the cards of history were stacked against Austria and Hungary, and the people of those countries were destined to pay heavily for the mistakes and blind spots of the Habsburgs." 30 The fall of the Habsburgs had shaken both Austrian and Hungary inflicting attrition, devastation, despair, and decay. ${ }^{31}$

Roosevelt was concerned about the Hungarian military, despite the fact that the Treaty of Trianon imposed strict limitations on its size. He understood that Hungary had not accepted the peace treaties "except through force." He knew that Hungarians aimed to regain their lost territories; therefore, he grew increasingly concerned that the potential and suspected "development of Hungary's military establishment could materially affect the peace of Europe., 32 Though he felt sympathy for Hungarians over the loss of historic Hungary, at the same time he clearly saw the dangers of Hungary's revisionist policies. The essence of his 
opinion concerning revisionism was summed up in a straightforward manner in the introduction which Roosevelt wrote to Regent Miklós Horthy's memoirs in 1956. The program, he says, "to try to restore to Hungary the boundaries it had had before the Habsburg [E]mpire broke up" was "a policy" which "however commendable to Magyars, ran counter to the nationalist aspirations and fears of non-Magyars, and was doomed to failure." 33

The strong nostalgic attachment to and longing for historic Hungary influenced the everyday life in Hungary both at the political and the social levels. As the lengthy quote above shows this Hungary of the 1930s for Roosevelt seemed a very different place, a bygone world, where "feudalism survived," where the old, deeply-rooted and rigid concepts of rank and title unquestionably overruled everything ${ }^{34}$ - a world, therefore, which Roosevelt viewed rather critically. The American diplomat, for example, dealt with and commented on the Habsburgs as well, including the last king of Hungary, King Charles IV and his unsuccessful attempts to return to the throne - taking issue with monarch who against the political realities, Roosevelt explains, still entertained the idea that the "throne of Hungary was his by divine sanction as well as by legal right." 35

The American minister had critical observations about the members of the upper classes of the aristocracy, the heads of the magnate families who, as Roosevelt contends, "seemed to be the survivors of a social system which was rapidly dying;" and whose genuinely paternalistic attitude towards the peasants - who would kneel down by the roadside and take off their hats in reverence when the lord of the manor rode by ${ }^{36}$ proved to be absolutely incongruent with the American's view of the world. He could never get used to such a social structure, indicative of which he accounts of several anecdotes in his memoirs.

"But the difference in points of view between the feudalism of eastern Europe and our own Western world was brought home to me by mere chance when I had been invited by the Regent to take part in a wild-boar hunt in mid-winter." 37 His company was standing hours in the snow, in the freezing cold. Anticipating this to happen, Roosevelt had a bottle of hot tea with some rum in his backpack. He did "what any American would have done without giving it a thought," and offered a cup to the gun bearer who was assigned to him. He was surprised, removed his hat and continued to hesitate to accept it. "It was obvious that this was the first time that he had been offered anything by those whom he was attending. When finally he took the cup and drank it, he still seemed 
incredulous, as if I had done something that just was not done by our best people, and as if he might be reproved for abetting my unconventionality." ${ }^{38}$ Roosevelt found the everyday manifestations of these rigid, hierarchical social relations - among them behavioral patterns and obligatory polite gestures to be rather awkward and definitely a nuisance. He could not come to terms with the extent to which people took prestige and pride in belonging to someone or serving someone. For example, Roosevelt became a true trial for the legation driver because of his insistence on opening the door of the car for himself. "Repeatedly, he made cordial and polite efforts to teach me the error of my way, but finding that I was impervious, he resorted to the expedient of having the handle of the door tightened in such a manner that I could not open it from the inside." 39

Roosevelt's above outlined critical views were somewhat balanced by his opinion of few - in his judgment - outstanding members of the Hungarian political elite, including, for example, Horthy ${ }^{40}$ and then Minister of Foreign Affairs Count Pál Teleki. Roosevelt held Teleki in high esteem. Teleki's intelligence and integrity made him an outstanding exception; and "by intellectual discipline," Roosevelt argued, he was a Western European:" 41 "Where other Hungarians sought to convince by impassioned speeches and extravagant arguments, he was cool, clear, and frank. He neither evaded nor denied facts which more biased Hungarians would have brushed aside angrily because they affected Hungary adversely." 42 Moreover, Roosevelt was astonished by the magnitude of the Apponyi phenomenon: the personality of the honorable and exceptional Count Albert Apponyi, whom Roosevelt acknowledged as "the most distinguished of the Hungarian aristocrats, both in character and intellect." $" 43$

\section{Conclusion}

Roosevelt returned home in 1933. His experience in politics and diplomatic service in Central Europe and Hungary amply paid off professionally in his career as a journalist and writer, as well as personally since he nurtured friendly relations with several Hungarian politicians long after his diplomatic service in Hungary ceased. ${ }^{44}$ Unlike Roosevelt, his successor John Flournoy Montgomery became a true admirer of Hungary during his mission in Budapest, he shared Roosevelt's fairly critical 
attitude toward Hungarian political issues in general, and treaty revision and the policies devised to achieve this goal in particular, and he also sensed clearly how powerful and dangerous a force revisionism was in Hungary during the 1930s. ${ }^{45}$

Roosevelt's memoirs - written in enjoyable prose and with great critical insights - offers us the opportunity to learn more about the perplexed nature of Hungarian history during the 1930s through the eyes of an American diplomat "from a front row seat", and proves to be an informative and compelling piece of reading for historians for history enthusiasts alike.

Notes

1 The National Cyclopedia of American Biography, 324-325; Garraty and Carnes, American National Biography, XVIII: 828-829; Saxon, "Nicholas Roosevelt, diplomat," 245.

2 Roosevelt, A Front Row Seat, 91: "Life in Paris as an inactive aide of an invisible President soon palled."

3 Mayer, Politics and Diplomacy of Peacemaking, 369; Secretary of State Robert Lansing to Professor Archibald C. Coolidge, U.S. Department of State, Papers Relating to the Foreign Relations of the United States, The Paris Peace Conference, 1919, II: 218.

4 See the documents in U.S. Department of State, Papers Relating to the Foreign Relations of the United States, The Paris Peace Conference, 1919, XII.

5 Roosevelt, A Front Row Seat, 91.

6 Roosevelt, A Front Row Seat, 91.

7 Roosevelt, A Front Row Seat, 101.

8 Roosevelt, A Front Row Seat, 118.

9 The National Cyclopedia of American Biography, 324-325; Garraty and Carnes, American National Biography, XVIII: 828-829. As a foreign correspondent of Neue Freie Presse Roosevelt fostered a close friendship with its owner and editor-in-chief, with "the vigorous, pugnacious, highly intelligent" Dr. Moritz Benedict; of whom Roosevelt jovially commented in his memoirs as follows: "It used to be said that, next to Dr. Benedict, the old Emperor Franz Josef was the most powerful man in Austria." In Roosevelt, A Front Row Seat, 94.

10 Roosevelt, A Front Row Seat, 187.

11 Garraty and Carnes, American National Biography, XVIII: 828-829.

12 Roosevelt, A Front Row Seat, vii.

13 Saxon, "Nicholas Roosevelt, diplomat," 245.

14 Roosevelt, A Front Row Seat, vii. 
15 Martin, Memoirs - Fact, Fiction, or Truthiness? Great Lakes Literary, http://www.greatlakeslit.com/memoirs (March 7, 2018). See also White, The Content of the Form.

16 Roosevelt, A Front Row Seat, viii.

17 Roosevelt, A Front Row Seat, viii.

18 Roosevelt, A Front Row Seat, 188.

19 Mathey, "The revision of the treaty of Trianon: unfounded political aspirations of Hungary concerning the United States", 187-199; Mathey, “Az amerikai kormányzati körök és a magyar revízió kérdése a két világháború között”, 109-126.

20 The National Cyclopedia of American Biography, 324.

218 Órai Ujság [Eight o'clock news], September 28, 1933. Box 5, Series 1. Correspondence, Nicholas Roosevelt Papers, Syracuse University Library, Syracuse University, Syracuse, NY, USA.

228 Órai Ujság, September 28, 1933. Box 5, Series I. Correspondence, Nicholas Roosevelt Papers. See also "Mit remélhet Magyarország Amerikától?"[What may Hungary expect from America?] Pesti Hirlap, October 12, 1930 in Box 3, Series VII. Correspondence, Nicholas Roosevelt Papers. See also "Október [...] az új amerikai követ. Beszélgetés a New York Times szerkesztőségében Nicholas Roosevelttel" [October [...] the new American minister. A conversation with Nicholas Roosevelt in the headquarters of The New York Times], Az Est, October 12, 1930 in Box 3, Series VII, Nicholas Roosevelt Papers.; Imre Déri, "Roosevelt követ beszél terveiröl s Magyarországról" [Roosevelt on his plans and Hungary], Amerikai Magyar Népszava, September 27, 1930 in Box 3, Series VII, Nicholas Roosevelt Papers; Emil Lengyel, "Old Budapest Goes American," New York Herald Tribune, March 31, 1931, 15 in Box 3, Series VII, Nicholas Roosevelt Papers.

23 Roosevelt, A Front Row Seat, 100.

24 See William R. Castle, Jr. to Joshua Butler Wright, March 8, 1929, William R. Castle, Jr. Papers, Herbert Hoover Presidential Library, West Branch, Iowa, USA. See also William R. Castle, Jr.'s diary entry on November 22, 1922, William R. Castle, Jr. Diaries, Houghton Library, Harvard University, Cambridge, MA, USA. These documents were available for the author with the courtesy of Associate Professor Tibor Glant of the University of Debrecen.

25 Roosevelt, A Front Row Seat, 94.

26 Roosevelt, A Front Row Seat, 90.

27 Roosevelt, A Front Row Seat, 112.

28 Roosevelt, A Front Row Seat, 112.

29 Roosevelt, A Front Row Seat, 112-113.

30 Roosevelt, A Front Row Seat, 118.

31 Roosevelt, A Front Row Seat, 92.

32 Nicholas Roosevelt to Secretary of War Patrick J. Hurley, January 14, 1931. The William R. Castle, Jr. Papers.

33 The draft of Roosevelt's introduction to the book attached to Nicholas Roosevelt to Robert Speller, the publisher of Horthy's memoirs, April 25, 1956. Box 4, Series I. Nicholas Roosevelt Papers. See also Horthy, Memoirs. 
34 Roosevelt, A Front Row Seat, 188.

35 Roosevelt, A Front Row Seat, 122.

36 Roosevelt, A Front Row Seat, 189.

37 Roosevelt, A Front Row Seat, 200.

38 Roosevelt, A Front Row Seat, 200.

39 Roosevelt, A Front Row Seat, 190.

40 Roosevelt offers many comments and observations about Horthy and his family, mostly pointing at the differences in character between them and the members of high aristocracy. See Roosevelt, A Front Row Seat, 192, 193, 201.

41 Roosevelt, A Front Row Seat, 202.

42 Roosevelt, A Front Row Seat, 201.

43 Roosevelt, A Front Row Seat, 202.

44 For example with Tibor Eckhardt, a Hungarian politician who lived in exile in the United States after 1941. For more see Kádár-Lynn, Tibor Eckhardt.

45 Frank, ed., Roosevelt követe Budapesten, 11-65. See also Montgomery's comments on golf, traveling, cuisine, viticulture, social life in Hungary in Box 1, Budapest Diplomatic Corps Exchanges, 1933-1937, The John F. Montgomery Papers. MS 353. Sterling Memorial Library, Yale University. Hereafter cited as The John F. Montgomery Papers. See also L. Nagy, “Amerikai diplomaták Horthy Miklósról.”

\section{Bibliography}

Frank, Tibor. Ed. 2003. Discussing Hitler: Advisers of U.S. Diplomacy in Central Europe, 1934-1941. Budapest: CEU Press.

Garraty, John A. and Carnes, Mark C. 1999. American National Biography, XVIII. Oxford: Oxford University Press.

Horthy, Miklós. 1957. Memoirs. New York: Robert Speller \& Sons.

Lynn, Katalin Kádár. 2007. Tibor Eckhardt: His American Years, 1941 1972. Boulder and New York: East European Monographs.

L. Nagy, Zsuzsa. 1990. "Amerikai diplomaták Horthy Miklósról, 19201944,” Történelmi Szemle 3-4: 173-196.

Martin, Philip. 2018. Memoirs - Fact, Fiction, or Truthiness? Great Lakes Literary. http://www.greatlakeslit.com/memoirs.

Mathey, Éva. 2013. "The revision of the treaty of Trianon: unfounded political aspirations of Hungary concerning the United States." Virágos, Zsolt K. (ed.) Hungarian-American Ties. Essays and Studies in Intercultural Links and Contacts. Debrecen: Debrecen University Press. 187-199. 
Mathey, Éva. 2014. “Az amerikai kormányzati körök és a magyar revízió kérdése a két világháború között." [Official America and the question of the revision of the treaty of Trianon between the world wars]. Aetas 29: 3: 109-126.

Mayer, Arno J. 1967. Politics and Diplomacy of Peacemaking. Containment and Counterrevolution at Versailles, 1918-1919. New York: Knopf.

Montgomery, John Flournoy. 1947. Hungary. The Unwilling Satellite. New York: The Devin-Adair Company.

Montgomery, John Flournoy. 2004. Magyarország, a vonakodó csatlós. Frank, Tibor. (ed.) Budapest: Zrínyi Könyvkiadó.

National Cyclopedia of American Biography. Current Volume F. 193942, New York, James T. White \& Co., 1942. 324-325.

Roosevelt, Nicholas. 1953. A Front Row Seat: A Sparkling Narrative of the History-Making Events in Which Mr. Roosevelt Has Participated, and the Notable Figures He Has Known, Especially the Roosevelt Family. Norman: University of Oklahoma Press.

Saxon, Wolfgang. February 18, 1982. "Nicholas Roosevelt, diplomat," The New York Times Biographical Service. https://www.nytimes.com/1982/02/17/obituaries/nicholas-roosevelt.

U.S. Department of State, Papers Relating to the Foreign Relations of the United States, The Paris Peace Conference, 1919. Vol. II. Washington, D. C., US Government Printing Office, 1947.

U.S. Department of State, Papers Relating to the Foreign Relations of the United States, The Paris Peace Conference, 1919. Vol. XII. Washington, D. C., US Government Printing Office, 1947.

White, Hayden. 1987. The Content of the Form: Narrative Discourse and Historical Representation. Baltimore: The Johns Hopkins University Press.

\section{Archival sources}

John F. Montgomery Papers. Sterling Memorial Library, Yale University. Nicholas Roosevelt Papers. Syracuse University Library, Syracuse University, Syracuse, NY, USA.

Box 3, Series VII. Correspondence. 
Box 4, Series I.

Box 5, Series I. Correspondence.

William R. Castle, Jr. Papers. Herbert Hoover Presidential Library, West Branch, Iowa, USA.

William R. Castle, Jr. Diaries. Houghton Library, Harvard University, Cambridge, MA, USA. 